\title{
Spectral Filtering of Photovoltaic Cells Using Novel Bio-Filter: Silver Coated Ixora Extract Using Methanol Solution
}

\author{
Emetere Moses E. ${ }^{1,2, *}$, Adeyemo Nehemiah ${ }^{1}$ \\ ${ }^{1}$ Department of Physics, Covenant University Canaan Land, Nigeria \\ ${ }^{2}$ Department of Mechanical Engineering Science, University of Johannesburg, South Africa
}

Received August 25, 2019; Revised September 24, 2019; Accepted October 5, 2019

Copyright@2019 by authors, all rights reserved. Authors agree that this article remains permanently open access under the terms of the Creative Commons Attribution License 4.0 International License

\begin{abstract}
Photovoltaic (PV) solar panel imported into Africa was observed to have low lifespan due to the spectrum of harmful solar radiation hitting the surface of the PV panel. In this research, the bio-filter was synthesized using plant extract and silver. The dark room experiment was carried out to examine capacity of the PV panel accept specific radiations. The bio-filter was sprayed on the PV panel and the measurement for a sprayed and unsprayed PV panel were obtained. It was discovered that the bi-filter was effective to stabilize the measured parameters such as current, voltage and power.
\end{abstract}

Keywords Photovoltaic, Bio-Filter, Spectral Filtering, Solar Energy, Energy

\section{Introduction}

Photovoltaic (PV) cell technologies do not discharge or emit greenhouse gases directly and can save over 30 million tons of carbon per exajoule of electricity generated in comparison to natural gas turbines running at about $45 \%$ efficiency. Unlike fossil fuels, it is eco-friendly and have existed for over a thousand years. Photovoltaic cell (PV) is categorized by constraints that are determined by the producers when tested under the Standard Test Conditions (STC), that is irradiance of $1000 \mathrm{~W} / \mathrm{m}^{2}$, constant temperature of the cells at $25^{\circ} \mathrm{C}$, and the AM1.5 standard sunlight spectrum $[1,2]$. Though, these parameters cannot be used to estimate the energy output of a module under real operating conditions, because of different environmental factors, geographical location of the module and spectral response of each PV technology that will affect the module in a real operating condition[1-3]. Thin-film and other advanced technologies will have a large input in the output improvement of PV cells in the nearest future. However, research already shows that the mono and poly-crystalline silicon cells of about $85 \%-90 \%$ vastly represent the PV market $[3,4]$.

The solar market is receiving low patronage in Africa due to the high cost of maintenance $[5,6]$. This cost is unnecessarily high because PV panels are almost not functioning two years after purchase. The major challenges facing renewable energy installation in Africa are the lack of technical skill and knowledge and the insufficiency of technologically advanced energy data gathering tools $[7,8]$. African countries rely on the data that the developed nations have already collected, most of which are inaccurate due to location difference in data collection. Since, there are low ground data measurements in most parts of Africa, it becomes very tricky to invest on a technology that is not known. However, scientists in the region have adopted the remote satellite measurement to perform preliminary studies. These assessments have enlightened energy provider [9-12]. Moreover, the continent's poor technical skills affect the sustainable development of renewable energy technologies. For example, the challenges of PV system working below $50 \%$ of its capacity is a major challenge that has not been addressed for the past one decade of active use of PV panels in Africa. This challenge has aggravated the coat of maintenance of solar equipment in the region. In this research, bio-filter was synthesized using metallic coated plant extract. The bio-filter is expected to filter-away harmful radiation hitting the PV panel. This process is called spectra filtering. There are on-going research works on the subject matter [13-16]. The energy sectors in developing nations are encountering numerous issues and problems regarding financial mobilization. Since, the standalone user bears the bulk of the liabilities of using the solar energy option, investments in renewable energy 
systems are incredibly low due to weak government aid.

\section{Materials and Method}

The materials used for the experiment includes: monocrystalline panel (3watt), solarimeter, silver Nitrate $\left(\mathrm{Ag}_{2}\left(\mathrm{NO}_{3}\right)\right)$, colour filters, polycrystalline panel (4 watt), halogen lamp, methanol solution, multimter, weighing balance, beaker and data logger.

The dark room experiment was carried using different colour filter as shown in Figure 1. Different colour filter was used to filter the spectra of light hitting the solar panel.
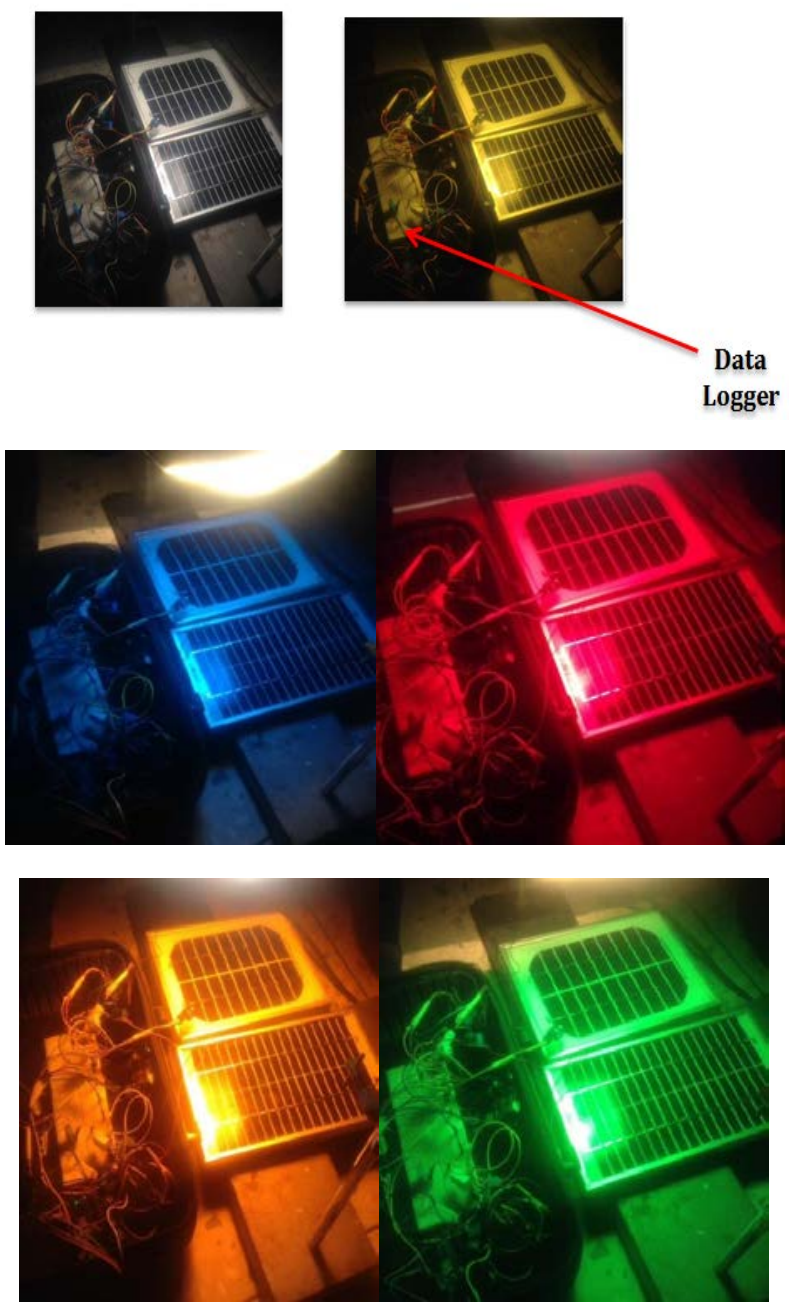

Figure 1. Spectral filtering using colour filter in the dark room

The data logger was used to measure desired parameters such as radiation, current, voltage and power for two types of PV panels i.e. monocrystalline and polycrystalline. A data logger records and saves all readings gotten from the PV panels in an SD card. The dark room experiment is to help understand the result gotten from the darkroom when compared with the data or result gotten from the silver coated plant extract The colour of the filters used for the experiment are yellow, white, blue, orange, green, yellow and red. The filters were selected from the component of visible radiation (VIS) whose wavelength range is between $400 \mathrm{~nm}$ and $800 \mathrm{~nm}$, which can be perceived by the human eye. The target of the biofilter is to screen-out infra-red radiation. infrared (IR) radiation covers the wavelength range above $800 \mathrm{~nm}$ and is subdivided in IR-A, IR-B and IR-C ranges

The biofilter was synthesized in the laboratory using ixora flower extract and silver oxide. The ixora flower were gotten around the Ota environ, Nigeria (Figure 2a). The flowers were divided into four parts. Each portion of the flower was grinded (using electronic blender) in $25 \mathrm{ml}$ of water $\left(\mathrm{H}_{2} \mathrm{O}\right)$, methanol $\left(\mathrm{CH}_{3}-\mathrm{OH}\right)$, ethanol $\left(\mathrm{C}_{2} \mathrm{H}_{5}-\mathrm{OH}\right)$ and butanol $\left(\mathrm{C}_{4} \mathrm{H}_{9}-\mathrm{OH}\right)$. After blending, extracts were filtered out and mixed with $1.84 \mathrm{~g} /$ mole of silver oxide $\left(\mathrm{Ag}_{2} \mathrm{O}\right)$ and then left for a day so that the silver oxide can dissolve with the mixture. The filtrate was not heated to conserve vital chemical components. The filtrate was sprayed on the PV module as illustrated in Figure 2b. The two-polycrystalline PV panels (i.e. one panel sprayed with the biofilter and the second panel not sprayed) and four monocrystalline panels (i.e. two sprayed with the biofilter and the other two panels not sprayed) were connected to the data logger as shown in Figure 3.

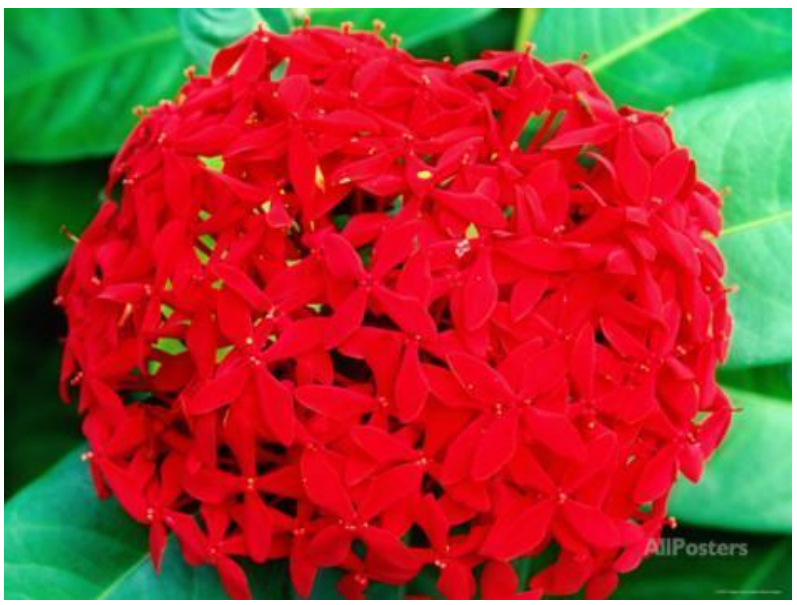

Figure 2a. Ixora flower

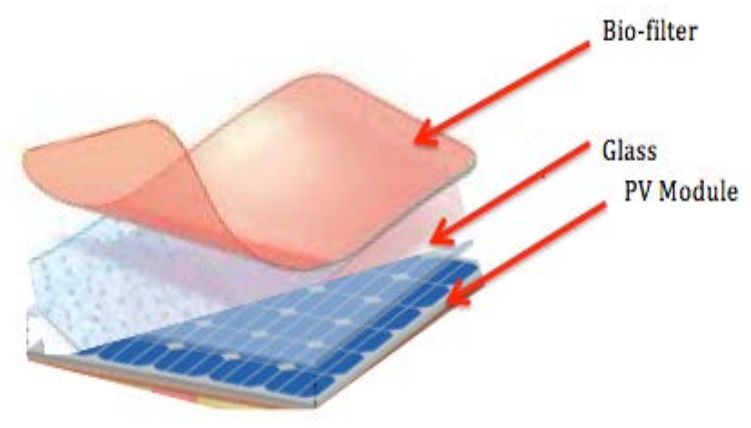

Figure 2b. Biofilter on the PV module 


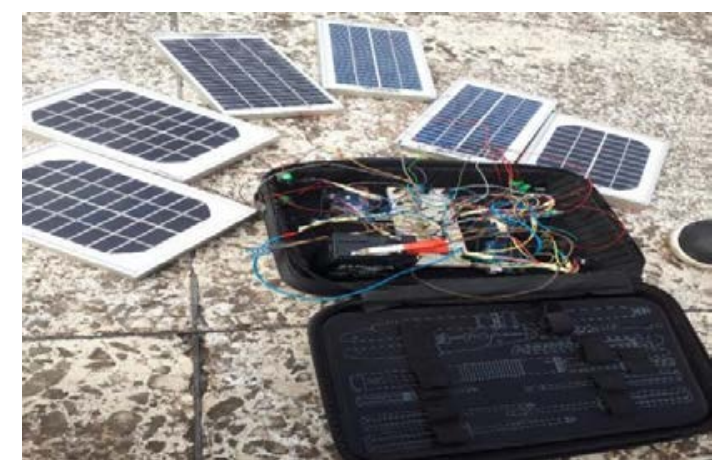

Figure 3. Experimental set-up for field measurement

Figure $2 b$ explains the essence of the experimentation as the bio-filter is expected to be sprayed over the PV module with high precision. However in this research, the precision on the thickness of the layer was not measured but can be estimated by knowing the volume of liquid sprayed on the PV module. The simplest way of knowing the expected thickness of the bio-filter is:

$$
\text { Thickness }=\frac{\text { Volume of bio }- \text { filter }}{\text { Surface area of PV Module }}
$$

It is recommended that for a more precise determination of the uniform thickness of the biofilter, spray pyrolysis should be used.

\section{Results and Discussion}

Figure 4 shows the dark room experiment when the polycrystalline panels are connected in parallel. It was observed that the white, orange, yellow and red colour filters generated high values of power. The white colour filter had the normal trend expected. The orange, yellow and red colour filters had a unique power pattern. In other words, the colour filter experiment shows that the PV panel responds to certain colours. This result agrees with already established research in this area of study [17]. Also, theoretical, the wavelength of the preferred colour filter corroborates the choice of the filter. The wavelength of red falls between 622 and 780 nanometers, while that for orange is 597 to 622 nanometers. The wavelength for yellow is 577 to 597 nanometers. Hence the need to choose plant extracts of such colour as bio-filter.

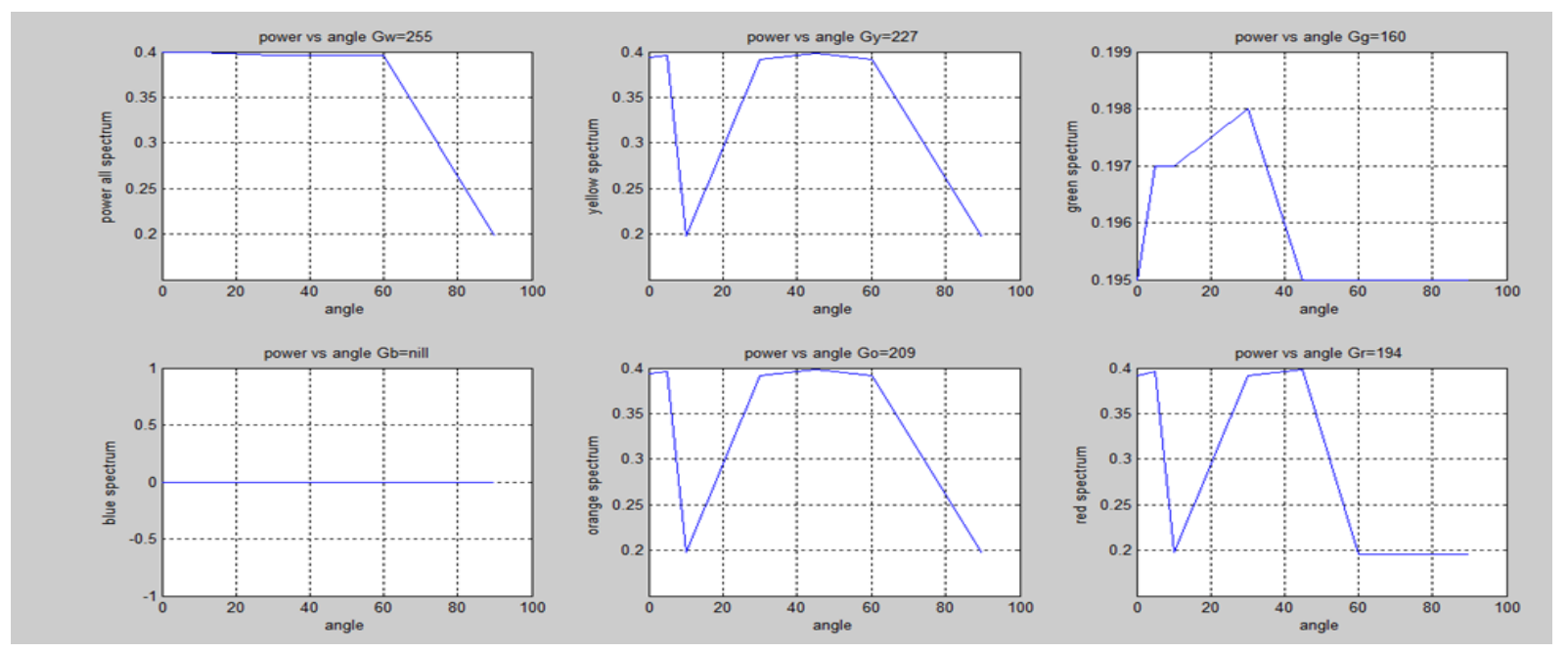

Figure 4. Darkroom experiment for color filters on polycrystalline panel 
The graph below (Figure 5) shows the UV radiation $\left(\mathrm{w} / \mathrm{m}^{2}\right)$ against time (sec) plot of the silver coated ixora extract in methanol solution for the polycrystalline panel. The graph shows stability over the time a period of time (1000-4300 sec). The UV over the period had an average of $16 \mathrm{~W} / \mathrm{m}^{2}$. It is observed that there were positive fluctuations at time between 5000 and $8000 \mathrm{sec}$. Also, there were negative fluctuations of UV between 4400 and $6000 \mathrm{sec}$. It can therefore be said that the graph is both stable and transient in nature. The trend of UV radiation is very important in research as it has both beneficial and harmful effects depending upon the type of organism or material (e.g. PV cells), wavelength region (UVA, UVB, or UVC) and irradiation dose (i.e. intensity within a specified duration). In this case, the radiation was found in the UVC i.e. hard UV. This event is common to tropic region were solar irradiance are interfered by cloud movement or modulating corrective weather system [10].

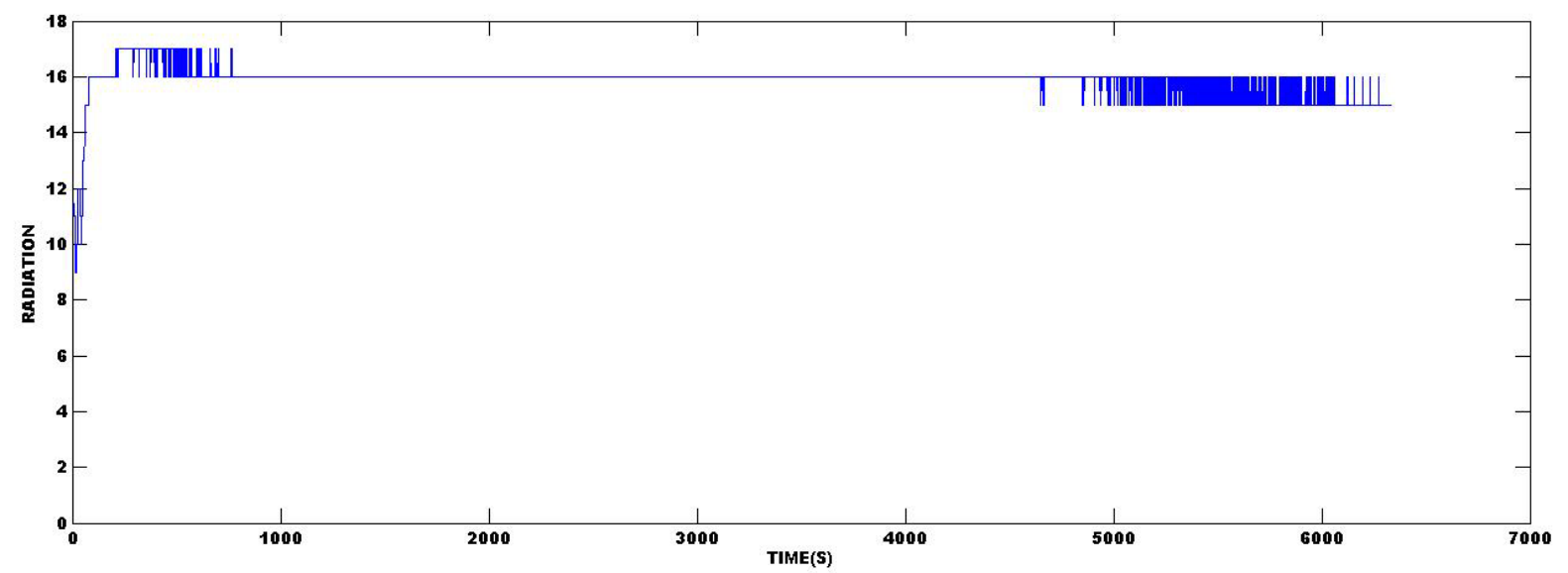

Figure 5. UV radiation $\left(\mathrm{w} / \mathrm{m}^{2}\right)$ against Time (sec) (polycrystalline panel)

The graph below (Figure 6) shows the voltage (V) against time (sec) plot of the silver coated ixora extract in methanol solution for the polycrystalline panel. The graph is both a linear and a transient graph, it shows a stable linear decrease at time $0-1700 \mathrm{sec}$ and also at time 4000-6200 sec. The perturbations in the graph show the transient portion of solar radiation over the research site. The blue colour shows the coated panel while the green shows the uncoated panel for the polycrystalline panel. From the graph it can be observed that the voltage of both panels gave almost the same result, but there was a slight increase in the voltage of the coated PV panel.

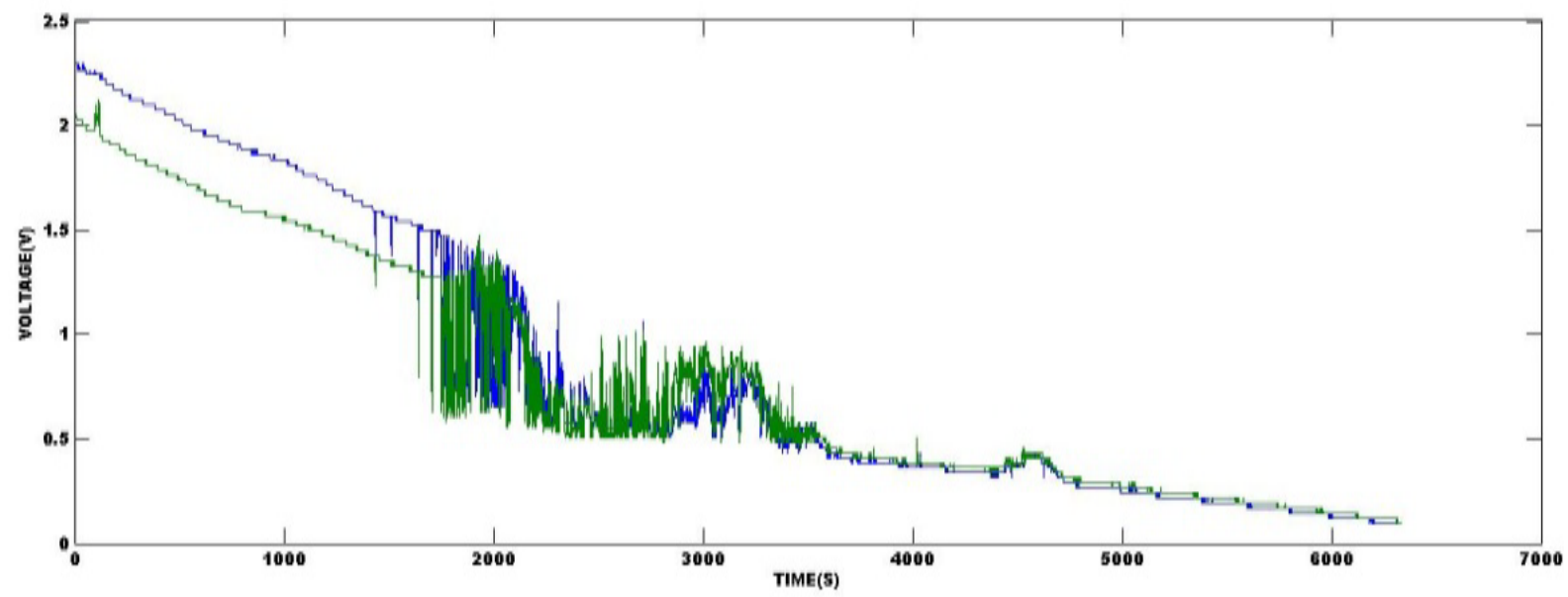

Figure 6. Voltage (V) against Time (sec) of silver coated ixora extract in methanol solution for the polycrystalline panel

The graph below (Figure 7) shows the current (A) against time (sec) plot of the silver coated ixora extract in methanol solution for the polycrystalline panel. At time 700sec the as a sharp increase current and suddenly a stable linear decrease for both PV panels. The blue colour shows the coated panel while the green shows the uncoated panel for the polycrystalline panel. From the graph it can be observed that the current of both cells compared to each other gave almost the same result, but there was a slight increase in the current output of the coated panel. 


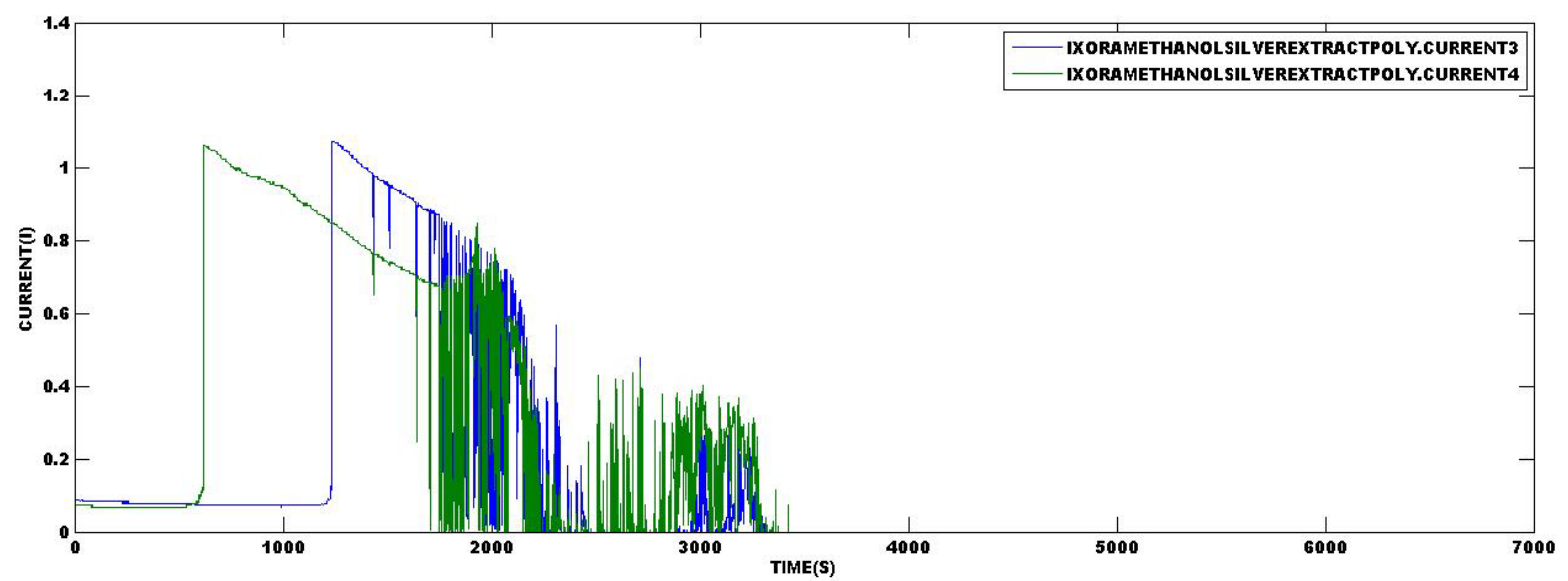

Figure 7. Current (A) against Time (sec) of silver coated ixora extract in methanol solution for the polycrystalline panel

The graph below (Figure 8) shows the power (W) against time (sec) plot of the silver coated ixora extract in methanol solution for the polycrystalline panel. The blue colour shows the coated panel while the green shows the uncoated panel for the polycrystalline panel. From the graph it can be observed that the power generated in both panels have almost the same result, this is because there has already been an increase in the currents and voltages of the polycrystalline panels. The graph is both linear and transient in nature. This means that though the bio-filter cannot control the trend of the solar radiation, it has the ability to make irradiance assimilation smoother.

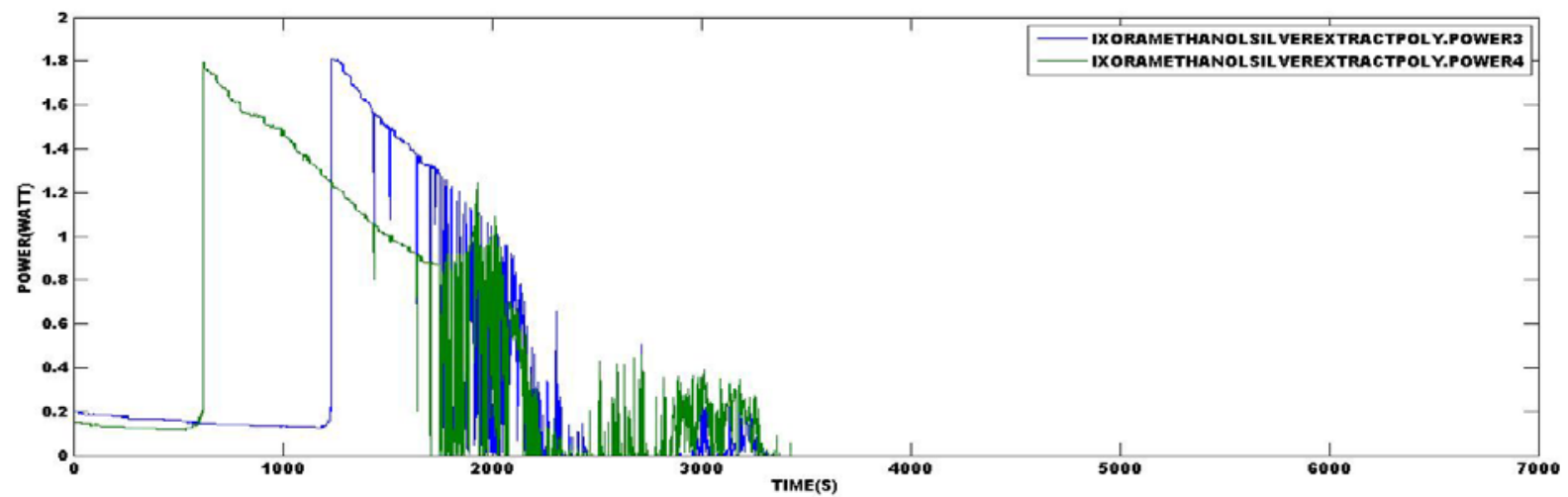

Figure 8. Power (W) against time (sec) of the silver coated ixora extract in methanol solution for the polycrystalline panel.

The graph below (Figure 9) shows the UV radiation $\left(\mathrm{w} / \mathrm{m}^{2}\right.$ ) against time (sec) plot of the silver coated ixora extract in methanol solution for the monocrystalline panel. The graph shows a stepwise increase in UV radiation. The UV over the period was at its peak at $(4000-4200 \mathrm{sec})$ and measured as $62 \mathrm{~W} / \mathrm{m}^{2}$.

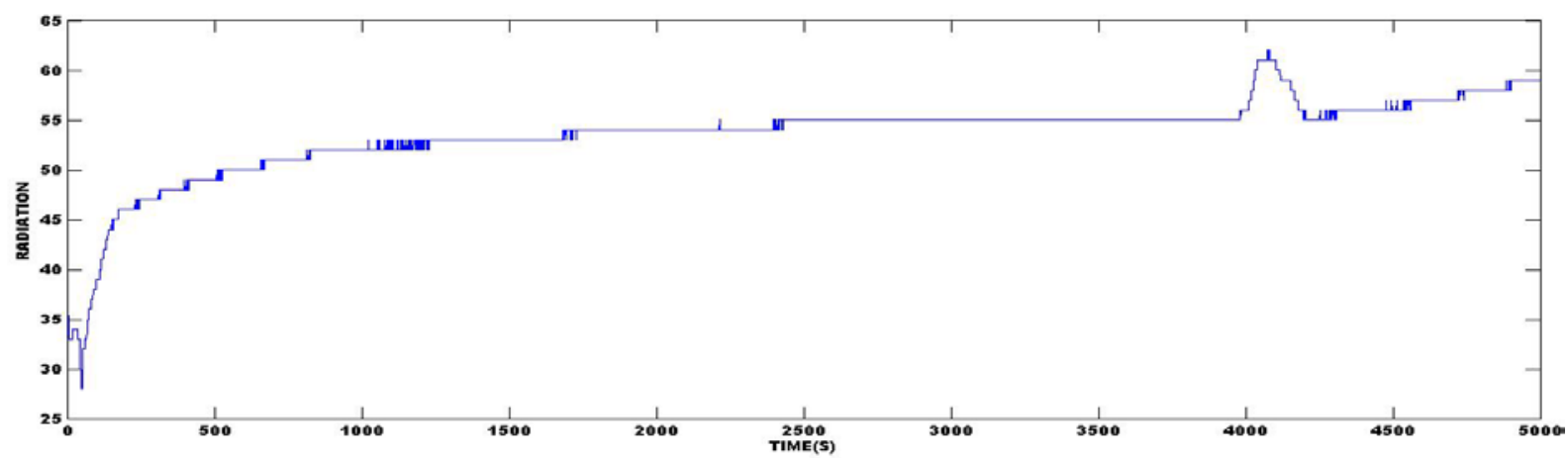

Figure 9. UV radiation $\left(\mathrm{w} / \mathrm{m}^{2}\right)$ against Time (sec) of the silver coated ixora extract in methanol solution for the monocrystalline panel 
The graph below (Figure 10) shows the voltage (V) against time (sec) plot of the silver coated ixora extract in methanol solution for the monocrystalline panel. The blue colour shows the coated panel while the green shows the uncoated panel for the polycrystalline panel. From the graph it can be observed that there was a drastic increase in the voltage output of the coated panel i.e. $>10 \%$ voltage increase. However, both panels had stepwise increase at some points and its peak at $4000-4300 \mathrm{sec}$. This graph shows that the bio-filter was effective to screen the harmful spectra and allow the panel function at optimized state.

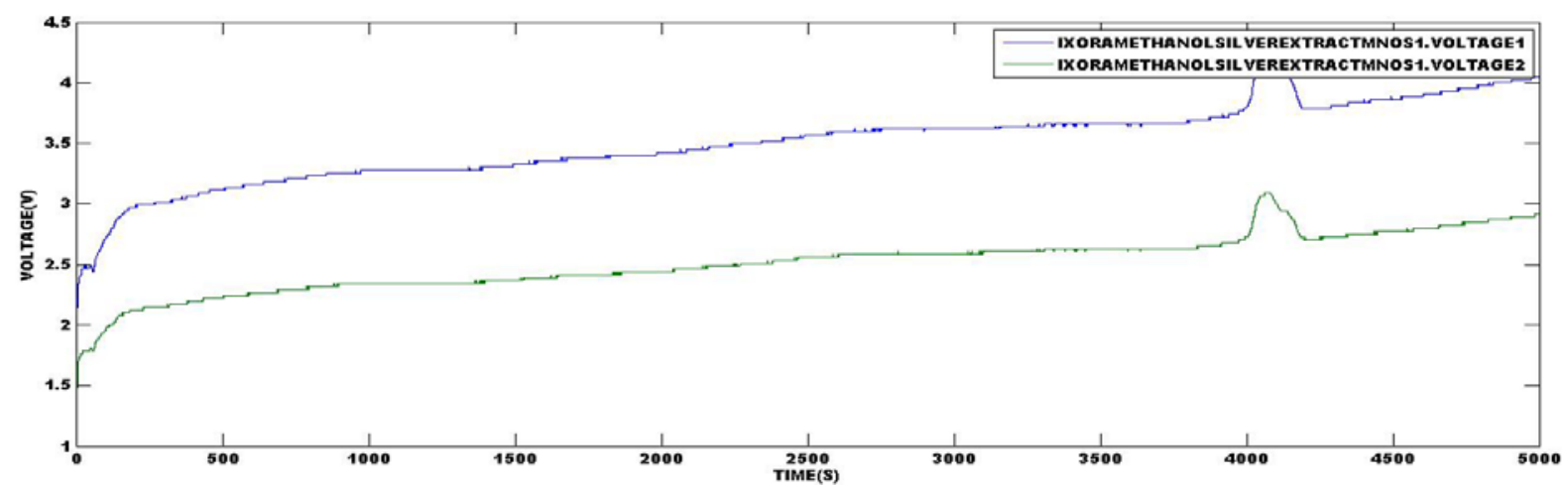

Figure 10. Voltage (V) against Time (sec) of the silver coated ixora extract in methanol solution for the monocrystalline panel.

The graph below (Figure 11) shows the current (A) against time (sec) plot of the silver coated ixora extract in methanol solution for the monocrystalline panel. The blue colour shows the coated panel while the green shows the uncoated monocrystalline PV panel. From the graph it can be observed that the current for the coated panel at $200-500$ sec was very high then started drop with respect to time as radiation reduced until it became lower than the uncoated panel. Most time high surface temperature can be responsible for this kind of current generation [18].

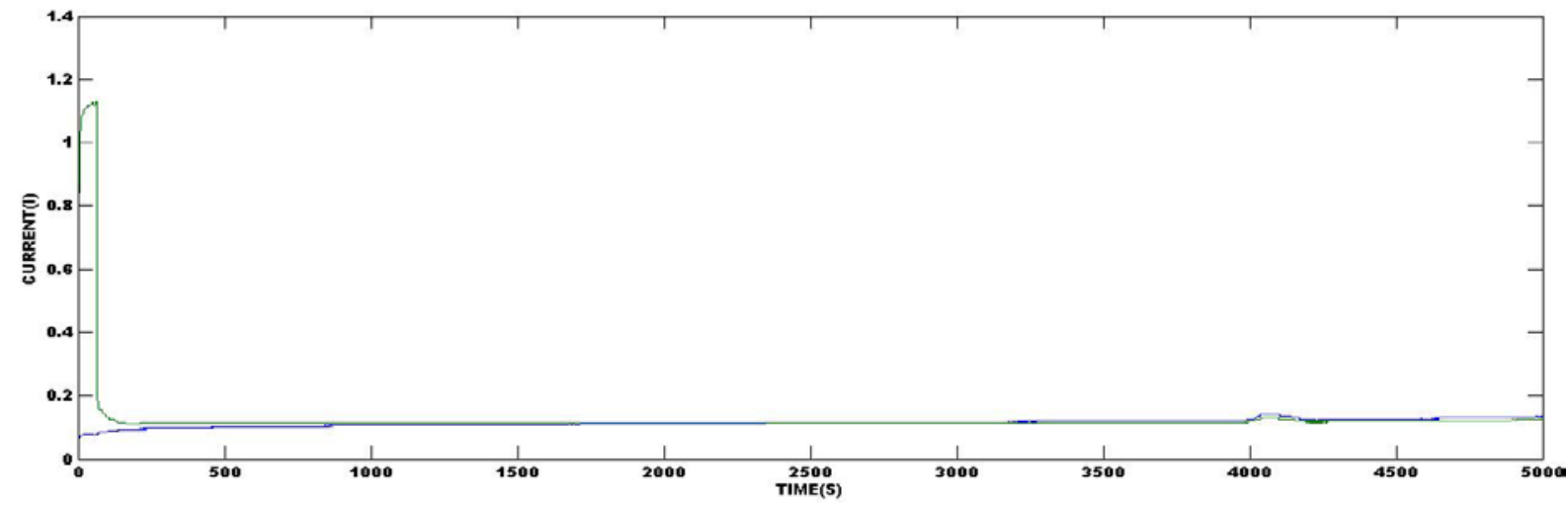

Figure 11. Current (A) against Time (sec) of the silver coated ixora extract in methanol solution extract for the monocrystalline panel.

The graph below (Figure 12) shows the power (W) against time (sec) plot of the silver coated ixora extract in methanol solution for the monocrystalline panel. The blue colour shows the coated panel while the green shows the uncoated panel. From the graph it can be observed that the power generated in the coated panel at was very high and dropped lower than the uncoated panel. The power generation is connected to the current generation in the panel. 


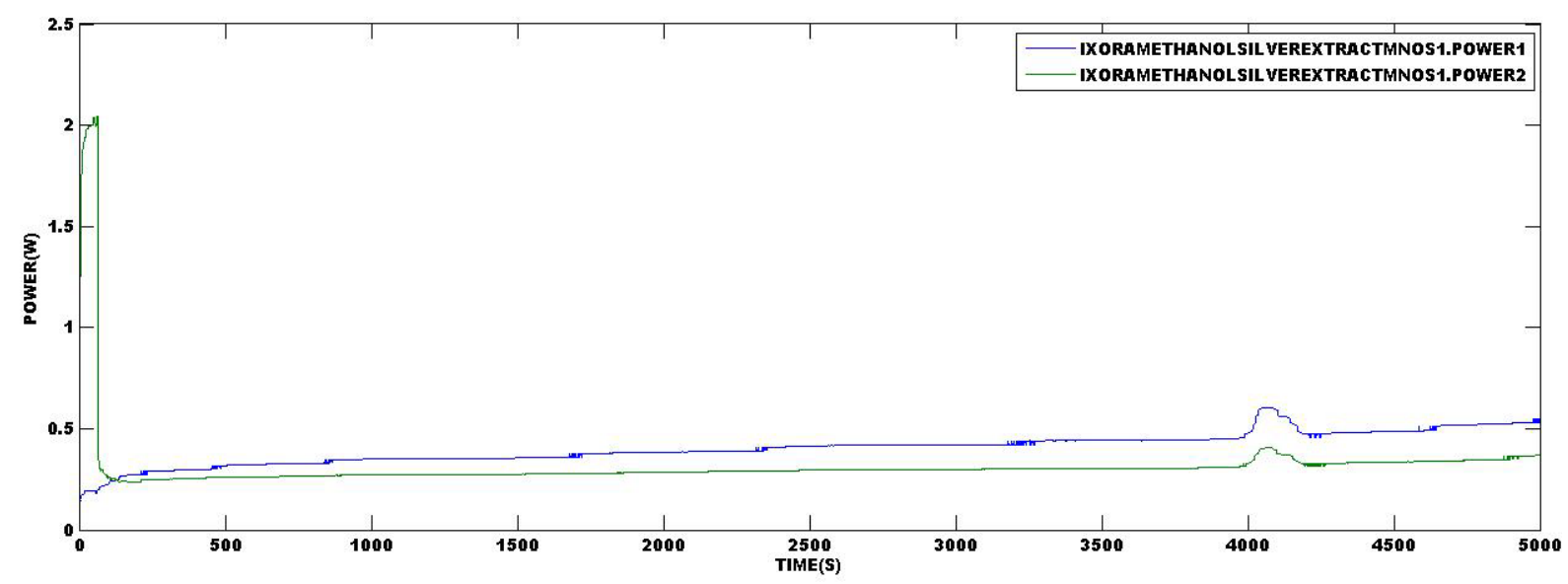

Figure 12. Power (W) against Time (sec) of the silver coated ixora extract in methanol solution for the monocrystalline panel.

\section{Conclusions}

From the research, it can be affirmed that the bio-filter was very effective to increase the voltage output of the monocrystalline and polycrystalline PV panel to $>10 \%$. Hence, the bio-filter was effective to screen the harmful spectra and allow the panel function at optimized state. The optimized state may include the application of state-of-the-art equipment for the synthesis of the bio-filter. Also, the biomass selection and component extraction should be well defined to maintain the red, orange or yellow extract. However, this research can still be improved in certain ways and as such, it is highly recommended that solar PV panel manufacturing companies should improve this experiment by making a sheet coated with the silver coated plant extracts to improve PV patronage in Africa.

\section{Acknowledgements}

The authors wish to appreciate Covenant University for partial sponsorship.

\section{REFERENCES}

[1] Janos T., and Elza K. (2008). Study of interconnections of solar cell within a solar panel to tackle the shading problem. Physical review, 18(1): 127-134

[2] Arnulf J. W., Fabio M. F., and Sándor S. (2015). Exploiting existing Dams for solar PV system installations. Journal of the American Astronomical Society, 7(9): 12340-12358

[3] Hugo A., Tiago M., Antonio V., Diana G., Manuel J.M., and Schimidt A. (2015). Thin film silicon PV cell. Physical review, 5(9): 364-382

[4] Brennan M. P.,Abramase A. L., Andrews R. W., and Pearce J. M. (2014). Effects of spectral albedo on solar photovoltaic devices. International Journal and scientific and engineering research, 124: 111-116

[5] J. Amankwah-Amoah, (2015), Solar energy in Sub-Saharan Africa: the challenges and opportunities of technological leapfrogging, Thunderbird Int Bus Rev, 57: 15-31

[6] Yomi Kazeem, (2018), The biggest obstacle to deploying solar energy in Africa is skepticism in high places, https://qz.com/africa/1238545/the-biggest-obstacle-to-depl oying-solar-energy-in-africa-is-skepticism-in-high-places/ (Acessed $7^{\text {th }}$ August, 2019).

[7] Wang, A. (2013). The Search for Sustainable Legitimacy: Environmental Law and Bureaucracy in China. Harvard Environmental Law Review, 37: 365

[8] Kostka, G., and W. Hobbs (2012). Local Energy Efficiency Policy Implementation in China: Bridging the Gap between National Priorities and Local Interests. The China Quarterly, 211: 765-785.

[9] Emetere M. E., Okoro U., Etete B., and Okunbor G., (2016), Free energy option and its relevance to improve domestic energy demands in southern Nigeria, Energy Reports, 2, 229-236.

[10] Emetere, M. E., and Akinyemi M. L., (2015) Weather Effect on Photovoltaic Module Adaptation in Coastal Areas, International Journal of Renewable Energy Research, 5(3), 821-825

[11] Moses E. Emetere, Marvel L. Akinyemi, and Etimbuk B. Edeghe, (2016). A Simple Technique for Sustaining Solar Energy Production in Active Convective Coastal Regions, International Journal of Photoenergy 2016, 3567502, 1-11, http://dx.doi.org/10.1155/2016/3567502

[12] Arnulf J. W., Fabio M. F., and Sándor S. (2015). Exploiting existing Dams for solar PV system installations. Journal of the American Astronomical Society, 7(9): 12340-12358

[13] Daniela D., Gina B., Björn M., and Christian R. (2014). Impact of solar spectral irradiance on the yield of different PV technologies. Fraunhofer ISE, Fraunhofer Institute for Solar Energy Systems, Heidenhofstrasse, Germany, 132: 431-442

[14] Huiye Q, Jianfei J, Ping Y, Tingge D, Jianyi Y, Hui Y, and Xiaoqing J (2016). Silicon bandrejection and band-pass 
filter, Department of Mechanical and Electrical Engineering, Longyan University, China, 41(11): $2450-2453$

[15] Brennan M. P.,Abramase A. L., Andrews R. W., and Pearce J. M. (2014). Effects of spectral albedo on solar photovoltaic devices. International Journal and scientific and engineering research, 124: 111-116

[16] Evaldo C. G., Pedro M. S., and Teófilo M. S. (2017). Spectral Response of Polycrystalline Silicon Photovoltaic Cells under Real-Use Conditions, Renewable Energy Center, School of Engineering, São Paulo State University (UNESP),10(8): 1178-1190

[17] Gouvêa, E. C., Sobrinho, P. M., \& Souza, T. M. (2017). Spectral Response of Polycrystalline Silicon Photovoltaic Cells under Real-Use Conditions. Energies, 10(8), 1178.

[18] M Emetere, S Sanni, O Dauda, A Akinsiku, O Osunlola, A Adejumo, (2019). Operational Trends of a mini parabolic solar collector for agricultural purposes in a non-active solar environment, Journal of Computational \& Applied Research in Mechanical Engineering 15:4 